\title{
Health Surveillance Integration System web-based for Health Centers
}

\author{
Riswandi ${ }^{1 *}$, A. Akhmad Qashlim (iD), Ul Khairat (iD ${ }^{3}$ \\ 1,2 Departement of Information System, Universitas Al Asyariah Mandar, Polewali Mandar, Indonesia \\ ${ }^{3}$ Departement of Informatics, Universitas Al Asyariah Mandar, Polewali Mandar, Indonesia
}

*riswandiandi093@gmail.com (coresponden author)

medqashlim@gmail.com

ul.khairat24@gmail.com

Article history :

Received : 7 Aug 2021

Accepted : 15 Aug 2021

Available online : 18 Sep 2021

\section{ABSTRACT}

Efforts to improve analytical skills provide recommendations and improve partner's cooperation in order to strengthen the surveillance system in each Health Center unit that can be utilized by the field of epidemiology for managers / structural and functional. So we need an automated system that is able to process and integrate disease data into surveillance data. This automated system can be created using web-based information technology. This study aims to design a web-based information system that processes disease data taken from patient medical records and disease reports at three health centers, namely Massenga Health Center, Matakali Health Center, and Pekkabata Health Center then presented as disease surveillance data at the Health Office. The focus of surveillance is on the disease, not the individual. Qualitative methods in this study were used to analyze each system at each health center. This system is built using the PHP and MySQL programming languages using the concept of database integration. This system will collect data from three samples of Health Center, then the incoming data will automatically be processed and analyzed so as to produce objective, measurable information that can be compared over time between health center as decision making material. The results of this study are surveillance data regarding the information of diseases and trends in diseases such as DBD, TBC, ISPA, Hipertensi at certain timeframes in each Health.

Keywords : Surveillance Data, Disease, Health Service, Health Center, Integration System, Website 
(c) (1) (2) 


\section{INTRODUCTION}

Surveillance is one of the analytical, systematic, and periodic activities of disease or health problems and conditions that affect the increase and transmission of disease so that countermeasures can be carried out effectively and efficiently through the process of data collection, processing, and information dissemination. Disease surveillance is an activity of systematic and continuous observation of data and information about the incidence of risk factors and conditions that influence their increase in order to obtain and provide information to direct effective and efficient countermeasures (Pramatama et all., 2013; Sugiarsi, 2014).

Technological developments can be applied to health surveillance activities, one of which is website-based information system technology. Information system technology can be integrated into health services, such as for health monitoring, health checks, health consultations, and health management. This study proposes a system engineering process on a surveillance system using the Waterfall model software engineering method.

This study aims to identify ongoing business processes in the health care system and redesign some business processes for disease prevention and surveillance in clinics and clinics based on web pages (Sugiarsi, 2014).

This study will collect medical record data from 3 Health center. Data from the Health center is used because it is the first health service that is reached by the community. Medical record data from 3 Health center will be integrated into one database, so that it can be informed to see disease groups, distribution and disease data based on patient domicile and disease tendencies.

\section{LITERATURE REVIEW}

\subsection{Health Surveillance System}

A surveillance system is needed to provide continuous and systematic information about the burden of a particular disease problem in the region. Surveillance is the continuous and systematic observation of disease in terms of the incidence, distribution and factors affecting disease in the community, from which effective action can be taken (Sugiarsi, 2014).

In article 6 , health surveillance is carried out through data processing, data analysis, continuous data collection, and dissemination as an inseparable unit to produce objective and measurable information that can be compared over time, between regions, and between community groups as material for decision making. decision.

Surveillance continuously monitors disease incidence and trends, detects and predicts outbreaks in the population, observes factors that influence disease incidence, such as biological changes in agents, vectors, and reservoirs. Furthermore, surveillance connects this information to decision makers so that disease prevention and control measures can be carried out.

A robust monitoring system provides adequate monitoring of the number, location, and timing of cases per person, providing robust information for disease prevention and management programmes. In addition, with proper monitoring, disease awareness and possible surveillance of diseases that may occur in the community can be achieved (Pratamatama et all., 2013; Sugiarsi, 2014).

\subsection{Medical record data processing}

Data processing is all kindsprocessing of data or a combinationof various kinds of data processing formake the data useful according todesired results, so that used.

The same is true for processing medical record data, which has various types of processing. The following are various types of medical record data processing:

a. Assembling is part of the medical record unit in charge of validating data to ensure completeness and archiving of documents.

b. Coding is the giving of disease codes based on letters/alphabets as representatives of certain data components.

c. Indexing includes aggregation using the code assigned to the index (can use index cards or computerized), types of indexes are Disease Index (diagnosis), Operation/Action Index, Doctor Index, Death Index, Drug Index, Region/Address Index, Index Number.

d. Filling (Storage) is an activity in archiving medical record documents so that they are maintained and stored properly.

e. Analyzing / Reporting is the process of analyzing a collection of data that forms medical record information as accountability and decision making from the resulting output (Puspitasari \& Purnama, 2018).

\subsection{System Integration}

System integration forms a series of processes that connect several computerized systems and application software. The concept of system integration is how to make the system interconnected or relevant to certain rules to provide information quickly and precisely and make it easier for management to coordinate (Yogiswara et all., 2014).

System integration is a key based on management coverage systems, both in economic management, health, and education where the concept of integration is expected because:

a. Components require cooperation between natural parts of society. 
b. As a result, data processing occurs between related departmental coverage systems and data must be exchanged using different coverage systems to complete reports.

c. It can provide real time data access.

Transform data for business analysis and data exchange, and manage data locations for performance, updates, and availability (Susanto, 2011). However, it is difficult to integrate data when there are disparities in the database structure to be integrated and the disparity in application platforms.

\subsection{Tools}

a. PHP (Hypertext PreProcessor) is a script that is integrated with html and is on the server (server side HTML embedded scripting) which is used to create dynamic web pages so that this mechanism causes the information received to be always new (Haerullah \& Ismiyatih, 2017);

b. MySQL (My Structure Query Language), it is a database management system software SQL (Database Management System) or DBMS that will function as a data storage medium for later display on the website (Prasetya, 2001);

c. XAMP is a software that functions to run PHP-based websites and uses MySQL data processing on a local computer. XAMPP functions as a server on a computer or a virtual server panel that can assist in previewing so that you can modify websites without having to be online or connected to the internet later (Qashlim, 2018).

\section{RESEARCH METHODS}

The materials used in this study were medical record data (diagnostic data and action data), surveillance data (disease trend data, disease distribution data at health centers, disease distribution data by region, disease distribution data by period) and patient data. From this data then make business rules to be embedded in the software. This study also uses literature studies in the form of articles, textbooks, and references that can support research. It is planned that this research will create a system design that can integrate the Health Center Surveillance data. For this reason, the following research steps were carried out:

a. Documenting the stages of recording medical records in each Health Center whose data will be integrated.

b. From the results of the documentation, data is obtained regarding procedures, rules, and related components that will be modeled in the design of the planned application.

c. System analysis is modeled into one form of system design.

d. Analyzing problems that arise in health services, especially surveillance data, which becomes information for the health department in conducting an analysis of the spread of disease.

e. From the problems that arise in the Surveillance data service, a more flexible service system is needed, in this case a Surveillance data integration system is developed. f. In the process of achieving a solution, it is hoped that conclusions will be obtained that will meet the research objectives and answer the hypothesis.

This research will adopt the waterfall model of software engineering. This model is the most widely used model by software developers (Robi et all., 2014).

There are five stages in the waterfall model, namely: Requirements Analysis, System Design, Implementation, Integration and Testing, Operations and Maintenance. As the name implies waterfall, the stages in this model are arranged in stages, each stage in this model is carried out sequentially, one before the other (see arrows) in Fig 1.

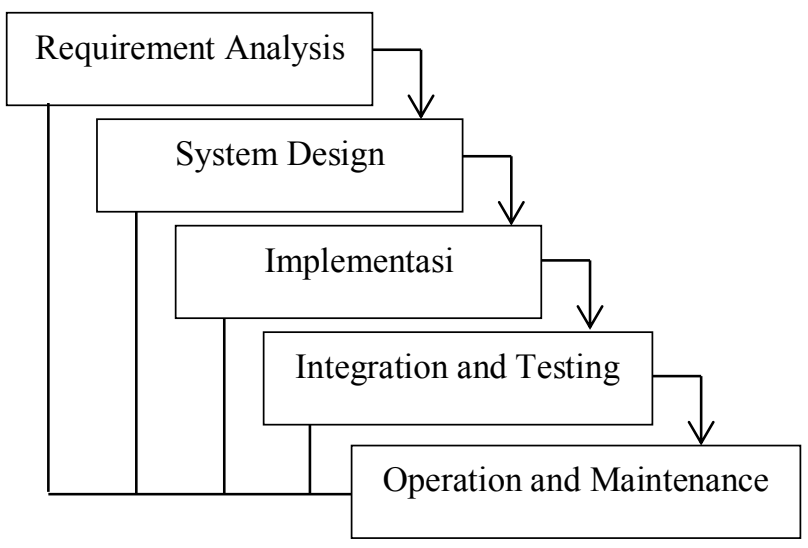

Fig 1. Waterfall model stages

The system developed is a simulation of the medical record data recording system at hospitals and health centers by limiting the system to outpatient recording. The flow of the medical record data recording system can be seen in Fig. 2.

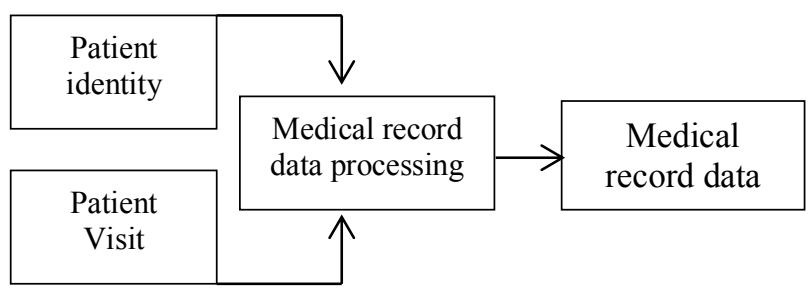

Fig 2. Medical record data flow

\section{RESULTS AND DISCUSSION}

The results of research on a website-based surveillance data integration system using the PHP and XAMPP programming languages, the program built must be in accordance with the design that has been designed so that it can meet user needs. In this case, the system design is translated into a standard programming language. The results of this study can be seen in the display below. 


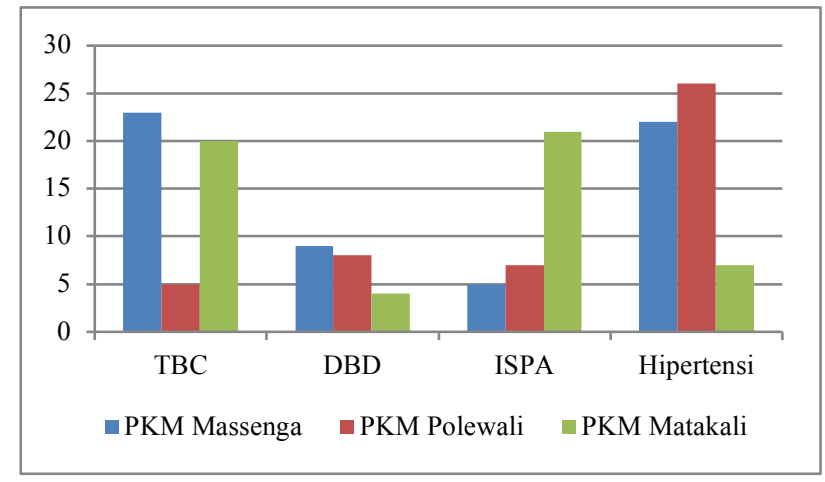

Fig. 3. Graph of disease distribution data at helath center

As shown in Fig. 3, illustrated the number of diseases in a health center which is then informed to the health office as an evaluation material in coordinating with the health center to disseminate information about the increasing disease in an area / area of the health center.

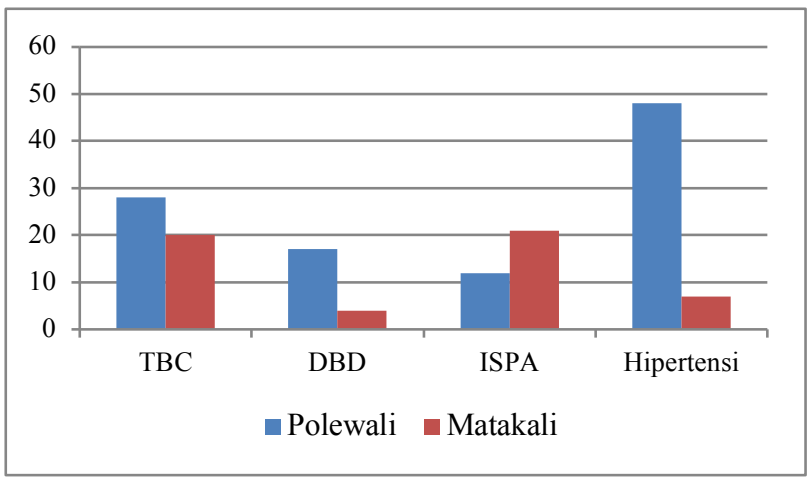

Fig. 4. Graph of disease distribution by region

We also see the Fig. 4, illustrated how many diseases there are in an area monitored by the health office. The presentation of data is obtained by inputting data input from each Health center, where the modules drawn to produce the data are patient data and patient examination data.

\subsection{Diseases Trend Analysis}

The disease trend data displays the results of the patient's disease tendency in terms of the history of the patient's previous examination using the following Formula (1). In Fig. 5, ilustrated trend of spread of disease.

$$
\text { Prevalence }=\frac{\text { total number of patient cases }}{\text { total population }}
$$

As we see in Fig. 5, will see illustrate what diseases are more likely to be deposited by people who come to check at the Puskesmas so that disease control can be carried out immediately in order to neutralize the disease to prevent/stop its transmission. Fig. 6, show that the distribution of diseases by period.

We can see in Fig. 6 above illustrates the development of the disease each year, so that in monitoring the health department from the data it can analyze what diseases continue to develop so that prevention is needed to stop the prevention.

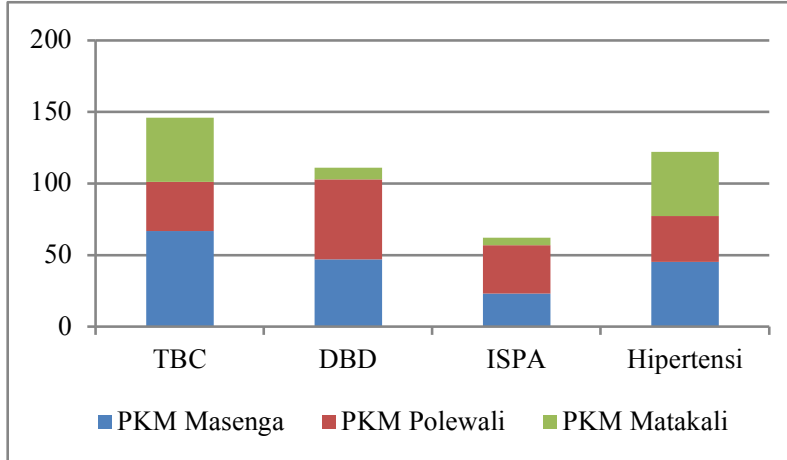

Fig. 5. Distribution of disease trend data

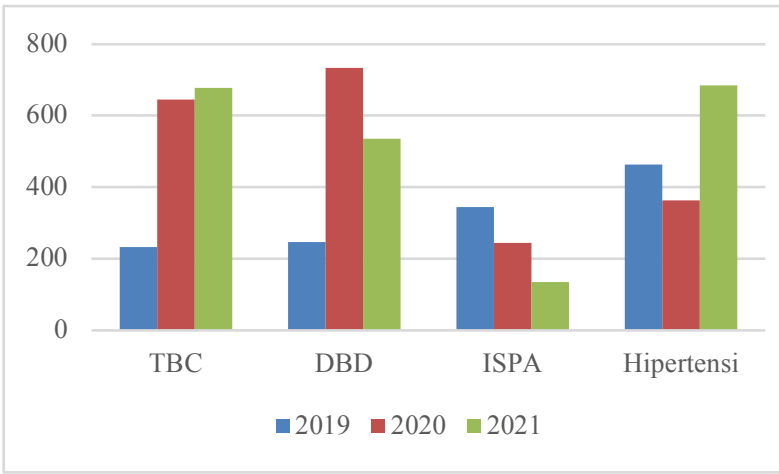

Fig. 6. Distribution of disease by period

With the prevention carried out by the Puskesmas through the coordination of the health office, it is hoped that the disease can be overcome.

\section{CONCLUSION}

The conclusion of the article entitled Integrated Health Center Surveillance Data System, namely, the system can store medical record data correctly then display the output of disease distribution data and disease surveillance data in the form of graphs so that patient medical record data information is more accurate and easy to find. With the existence of an integrated medical record data system in each Puskesmas, it can make it easier for health services to make referrals

Based on the research that has been done to date, there is still much that can be developed, such as integration of referral data, integration of outpatient and inpatient data, integration of medical record data between puskesmas and hospitals, as well as agency coverage, and additional features that will facilitate medical services when treating patients. Therefore, these are suggestions that the author can convey, and hopefully these suggestions can be used as a reference for conducting further research.

\section{REFERENCES}

Robi, Firmanda., Magdalena, Rita., \& Wijayanto, Inung. 
(2014). 1(1), 310-318.

Haerulah, E., \& Ismiyatih, S. (2017). Aplikasi ecommerce penjualan souvenir pernikahan pada toko “ XYZ .” Jurnal Prosisko, 4(1), 43-47.

Pramatama, S., Wijayanti, M., Octaviana, D., \& Anandari, D. (2013). Aplikasi teknologi sistem informasi geografis untuk meningkatkan sistem surveilans penyakit menular di kabupaten banyumas. 221-226.

Prasetya, H. (2001). Rumah Sakit Hewan Dan Arsitektur Modern. E-Journal Universitas Atmajaya Yogyakarta, 5-6.

Puspitasari, Y., \& Purnama, B. E. (2018). Sistem Informasi Rekam Medis. 1-6.

Qashlim, A. (2018). Integration of Information System Based on Supply Chain Management ( SCM ) for Pharmaceutical Warehouse in Mamasa Regency. 9(June),

$1-8$. https://doi.org/10.21512/comtech.v9i1.4027

Sugiarsi, S. (2014). Pengembangan Sistem Informasi Surveilans TB Berbasis Komputer Untuk Mendukung Evaluasi Hasil Kegiatan Program Penanggulangan TB (P2TB). Journal Speed Sentra Penelitian Engineering Dan Edukasi, 11(4), 33-40.

Susanto, G. (2011). Sistem Informasi Rekam Medis Pada Rumah Sakit Umum Daerah ( RSUD ) Pacitan Berbasis Web Base. 3(4), 18-24.

Yogiswara, Y., Wijono, W., \& Dachlan, H. (2014). Kinerja Web Service Pada Proses Integrasi Data. Jurnal EECCIS, 8(1), pp.73-78.

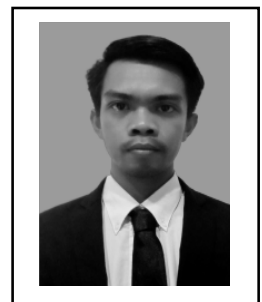

Riswandi Born on October 21, 1998, Student of Al Asyariah Mandar University, Interested in research on data analysis and health information.

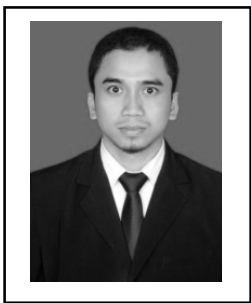

Akhmad Qashlim completed his master's study at the University of Diponegoro in 2014 and focused on research in the areas of systems analysis, health, and development.

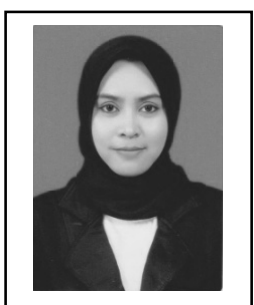

Ul Khairat completed his master's study at STIMIK HANDAYANI in 2018 and focused on research in the field of health and development. 